\title{
The Perception and Level of Digital Citizenship on Pre-Service Classroom Teachers*
}

\author{
Ceren Çevik Kansu' ${ }^{1}$, Yücel Öksüz ${ }^{2}$ \\ ${ }^{1}$ Ondokuz Mayis University, Faculty of Education, Department of Primary Education, Division of Classroom \\ Instruction Education, Samsun, Turkey \\ ${ }^{2}$ Ondokuz Mayis University, Faculty of Education, Department of Educational Sciences, Division of Guidance and \\ Psychological Counseling, Samsun, Turkey
}

Correspondence: Ceren Çevik Kansu, Ondokuz Mayis University, Faculty of Education, Department of Primary Education, Division of Classroom Instruction Education, Samsun, Turkey.

Received: July 4, 2019 Accepted: August 7, $2019 \quad$ Online Published: August 12, 2019

doi:10.11114/jets.v7i10.4443 URL: https://doi.org/10.11114/jets.v7i10.4443

\begin{abstract}
This study was aimed to determine of their perceptions and levels of digital citizenship for pre-service classroom teachers. The study was conducted with 76 senior pre-service classroom teachers at Education Faculty of B. U. The study is survey research. In this research, "The Digital Citizenship Scale" developed by Kocadağ (2012) was applied to the pre-service classroom teachers. By using open-ended questions that prepared by researchers, it was interviewed with the same students in order to making in-depth review. To determine digital citizenship levels, the frequencies, percentages, arithmetic means and standard deviations of obtained data were interpreted on the table. The data from the interviews were carried out with content analysis, which is one of the qualitative analysis methods, and had been interpreted. As a result, pre-service classroom teachers had been stated that they had no courses related with digital citizenship and its sub-dimensions during their higher education. Nevertheless, it has been found that they were correctly expressed the concept of digital citizenship. Pre-service classroom teachers have indicated that digital technologies were particularly utilized to aimed for online shopping, entering to social networking and researching of homework assignments in courses. Digital citizenship includes nine sub-dimensions that every individual should have in today's world. The classroom teachers, that play a key role in the training of the individuals must have been trained themselves by qualified properties before the beginning of their career. It is thought that this study might be leading to further studies by training on knowledge, ability and values about digital citizenship before beginning of their service to classroom teachers.
\end{abstract}

Keywords: pre-service classroom teacher, digital citizenship level, perception of digital citizenship

\section{Introduction}

The impact of technology on all areas of society, especially on human beings, has brought a new dimension to the concept of citizenship. Addressed as "digital citizenship", the concept of citizenship can now be defined as "acting in the awareness of every danger within the framework of ethical and universal rules in the internet environment" (Aydin, 2015, p. 142). Digital citizenship can also be called the "basic concept of modern democracy" (Missingham, 2009, p. 392). Digital citizenship also encourages students to respect themselves, the environment, and intellectual rights; while teaching critical thinking to protect the student from others, bad content and bad behavior in an online environment. The digital citizenship seeks to prepare children, new individuals of the digital world, for a technology-based society. Thus, citizenship education should be designed to be compatible with the needs of young citizens, and the social, political and communicative worlds in which they live (Bennet, Wells, \& Rank, 2009).

Educating individuals with the relevant skills can also be accomplished with the support of qualified teachers; recognizing the importance of the features that today's people need to have in order to be successful (Engin \& Sarsar, 2015). Considering that teachers have the chief role in molding a civilization into a knowledgeable society, it is essential to train and equip qualified teachers if there is a desire to enable and prepare society for a bright future (Gündüz \& Odabaşı, 2004).

*This study was presented at the XVII. International Classroom Teacher Symposium between 10-14 April 2018. 
It is expected that all the stakeholders in the education system will not fall behind technologically and will adapt to this rapid change; especially teachers and pre-service teachers, who are one of these stakeholders. These teachers should have certain competencies in this particular circumstance and be equipped to apply them appropriately for their students. While there are numerous studies on technology integration in education in the extant literature, it is observed that there are very few studies about whether teachers and students use technology appropriately, responsibly and ethically. With respect to the studies on digital citizenship and teacher education, it is evident that there is a great lack of research in the existing literature (Lindsey, 2015). While it is especially anticipated that students will have the skills of the $21^{\text {st }}$ century, with the varying needs of students, it is expected that teachers will also enable their students to gain these skills within the education system.

Pre-service teachers who are eager to use communication technologies, social networks and emerging and growing technologies, often do not know how to use these technologies in educational settings. As a consequence, it is reported that they cannot adapt the technology they have learned in their private lives, to the learning and teaching environment; are not able to transfer it; they are more likely to be content users rather than content creators (Kumar \& Vigil, 2011). Raising a good digital citizen is dependent upon the training received in schools regarding digital citizenship; which should start at the earliest age possible. Accordingly, teachers also need to be a good role models in the matter of digital citizenship.

Indeed, the technological competence standards of today are at a level that can be a model for teachers regarding digital citizenship; and they need to teach this concept to their students (Greenhow, 2010). Classroom teachers are expected to be a good model for digital citizenship at the primary school level, the most important period of education, as well. Considering the necessity of starting digital citizenship education at the beginning of primary school or even pre-school education (O'Brien and Stavert, 2011), the studies conducted with classroom teachers and pre-service has become more of an issue. In consideration of the notion that there are very few studies about new literacy concepts in the literature for primary school age children (Burnett, 2009) and this age group is important to gain basic skills, this particular study has been carried out. Within this process, the significance of teacher education becomes prominent and the training of qualified teachers equipped with the skills becomes the priority of the society. It is, therefore, believed that studies on digital citizenship and pre-service teachers will be a guide.

\section{Purpose of the Study}

The purpose of this study is to investigate the perceptions of the pre-service classroom teachers towards digital citizenship and sub-dimensions of digital citizenship, and to explore the perceptions about digital citizenship applications in undergraduate education.

To this end, the following questions were sought;

1. What are the digital citizenship levels of pre-service classroom teachers?

a. Is there any difference in the level of the digital citizenship among pre-service classroom teachers by gender?

b. Is there any difference in the level of the sub-dimensions of the digital citizenship among pre-service classroom teachers by gender?

2. What are the perceptions of pre-service classroom teachers towards digital citizenship and its sub-dimensions?

3. What are the perceptions and recommendations of pre-service classroom teachers regarding the applications of digital citizenship at the undergraduate education?

\section{Method}

The surveys method was employed to answer these research questions in this study. According to Karasar (2005), survey method may be aiming to describe an existing situation as it exists research approaches. The process of collecting the data needed for research is based on the answers to the questions posed to people with data sources (Büyüköztürk, 2009; Fraenkel \& Wallen, 2006). Through this method, perception and the level of digital citizenship on prospective classroom teachers were tried to determine.

\subsection{Participants}

Based on voluntary participation of the attendants, the sample of this study included 76 fourth-grade pre-service classroom teachers pursuing a degree at the Department of Primary Education in Education Faculty of Bayburt University (B. U.). Five of the participating students were excluded from the analysis due to coding errors. The reason for the selection of pre-service classroom teachers especially in the fourth year of undergraduate study is that they have more experience than the prospective classroom teachers who are studying at other grade levels. Because these prospective teachers have taken most of the courses and have more practical experience. 


\section{Data Collection Instruments}

The "Digital Citizenship Scale" developed by Kocadağ (2012) was utilized for measuring the digital citizenship level of pre-service teachers. The scale has seven sub-dimensions:

$1^{\text {st }}$ factor "Characteristics of Digital Communication and Literacy"

$2^{\text {nd }}$ factor "Characteristics of Digital Ethics and Law"

$3^{\text {rd }}$ factor "Characteristics of Digital Access"

$4^{\text {th }}$ factor "Characteristics of Digital Rights and Responsibilities"

$5^{\text {th }}$ factor "Characteristics of Digital Health"

$6^{\text {th }}$ factor "Characteristics of Digital Safety"

$7^{\text {th }}$ factor "Characteristics of Digital Trading"

Observing the presumed model fit among the factors of the scale, it was concluded that the construct validity of the scale was confirmed (Kocadağ, 2012), and thereby, the scale was used in the study. The total score range to be obtained from the Digital Citizenship Scale varies between 315 (maximum) and 63 (minimum). The levels of Digital Citizenship in association with the scores are depicted below in Table 1;

Table 1. Level of Digital Citizenship Scale

\begin{tabular}{l|l}
\hline Level & Score Range \\
\hline Extremely Weak & $63-98$ score \\
\hline Very Weak & $99-134$ score \\
\hline Weak & $135-170$ score \\
\hline Average & $171-206$ score \\
\hline Good & 207-242 score \\
\hline Very Good & 243-278 score \\
\hline Extremely good (excellent) & 279-315 score \\
\hline
\end{tabular}

The interview forms were developed in accordance with the research questions, and depending on the expert opinions, required corrections were made to obtain the final version of the questions. In Table 2, data collection tools regarding the research questions were displayed.

Table 2. Research and Data Collection Tools

\begin{tabular}{l|l|l|l|l}
\hline Research Question & $\begin{array}{l}\text { Target } \\
\text { Population }\end{array}$ & $\begin{array}{l}\text { Data } \\
\text { Collection } \\
\text { Tool }\end{array}$ & Type of Data & Data Analysis \\
\hline $\begin{array}{l}\text { 1. What are the digital citizenship levels of } \\
\text { pre-service classroom teachers? }\end{array}$ & $\begin{array}{l}4^{\text {th }} \text { Class } \\
\text { Pre-service } \\
\text { Teachers }\end{array}$ & Scale & Quantitative & $\begin{array}{l}\text { Descriptive } \\
\text { Statistics }\end{array}$ \\
\hline $\begin{array}{l}\text { 2. What are the perceptions of pre-service } \\
\text { classroom teachers towards digital } \\
\text { citizenship and its sub-dimensions? }\end{array}$ & $\begin{array}{l}4^{\text {th }} \text { Class } \\
\text { Pre-service } \\
\text { Teachers }\end{array}$ & Interview & Qualitative & Themes-Codes \\
\hline $\begin{array}{l}\text { 3. What are the perceptions and } \\
\text { recommendations of pre-service classroom } \\
\text { teachers regarding the applications of digital } \\
\text { citizenship at undergraduate education level }\end{array}$ & $\begin{array}{l}4^{\text {th }} \text { Class } \\
\text { Pre-service } \\
\text { Teachers }\end{array}$ & Interview & Qualitative & Themes-Codes \\
\hline
\end{tabular}

4.1 Data Collection and Analysis

The Digital Citizenship Scale developed by Kocadağ (2012) was administered to the pre-service classroom teachers, and the digital citizenship levels and demographic characteristics of the pre-service teachers were obtained. Afterwards, during the course of the teaching period of five weeks, the lectures of the pre-service teachers in classrooms were attended, and in the context of digital citizenship, pre-service teachers' lectures, their behaviors in the class and communication with the students, and their use of technology in the lessons were observed; observation notes regarding 
every lesson were recorded by the researchers. In the end, interviews were conducted with pre-service teachers regarding digital citizenship and its sub-dimensions and these interviews were recorded.

The digital citizenship level of pre-service classroom teachers was measured, according to the 'Digital Citizenship Scale' prepared for pre-service teachers. Descriptive statistical techniques have been utilized to analyze the respective quantitative data. Descriptive analysis of qualitative data analysis methods was employed for the analyses of the qualitative data obtained from observations and interviews.

Interviews were recorded using the interview form. For observations made in the classroom, the data were analyzed considering the standard indicators determined by ISTE (The International Society for Technology in Education). The raw data obtained was analyzed through descriptive analysis, depending on the research questions. During the course of the descriptive analysis, data was summarized and interpreted according to the themes defined beforehand. In the descriptive analysis, direct quotations are often reported in order to reflect the views of the interviewee or observed individuals notably. As a result, the data obtained is systematically and clearly described (Yıldırım and Şimşek, 2006). The data obtained as a result of the interview were analyzed within the framework of digital citizenship and its sub-dimensions.

\subsection{Validity-Reliability}

In this study, the "Digital Citizenship Scale", the reliability and validity of which was done by Kocadağ (2012), was utilized. Kocadağ (2012) checked the construct validity of the scale, through factor analysis. To the exploratory factor analysis performed, the scale had seven factors. Detecting the acknowledged model fit among the factors of the scale, it was interpreted by Kocadag (2012) that the construct validity of the scale was confirmed at an acceptable level. In the study, Cronbach Alpha coefficient as an indicator for the reliability of the scale was calculated as; .96 for factor $1 ; .94$ for factor $2 ; .86$ for factor $3 ; .74$ for factor $4 ; .80$ for factor $5 ; .79$ for factor $6 ; .75$ for factor 7 and .97 for the total scale, and it was concluded that the scale was reliable.

The administration of the scale is easy and economical in terms of time and cost, and the scoring of the scale is practical, which can be considered an indicator for the practicality of the scale in this study. During five weeks of the observation, the researcher did not interfere with the observations and act as a participant observer in the classroom environment. Depending on the research questions, interview questions were generated in accordance with the expert opinions. The analysis of the interviews was carried out by different researchers and the consistency of the analyses was checked.

\section{Results}

\subsection{The Digital Citizenship Levels of Pre-Service Classroom Teachers}

The total score received from the Digital Citizenship Scale corresponds to levels; extremely weak level covers the minimum score range (63-98); extremely good (excellent) level covers the maximum score range (279-315). As part of the sample of the study, pre-service teachers who received the Digital Citizenship Scale, were grouped according to their digital citizenship levels; the data are presented in Table 3.

Table 3. Digital Citizenship Levels of Pre-service Teachers Depending the Scores Obtained from the Digital Citizenship Scale

\begin{tabular}{l|l|l}
\hline Level & f & $\%$ \\
\hline Extremely Weak & & \\
\hline Very Weak & - & - \\
\hline Weak & - & - \\
\hline Average & 2 & 2.6 \\
\hline Good & 4 & 5.3 \\
\hline Very Good & 20 & 26.3 \\
\hline Extremely good (excellent) & 38 & 50.0 \\
\hline Total & 76 & 15.8 \\
\hline
\end{tabular}

As presented in Table 3, there are no pre-service classroom teachers in the sample $(\mathrm{N}=76)$ which are at extremely weak and very weak levels; $2.6 \%$ of the pre-service classroom teachers are at a weak level; $7.9 \%$ of the pre-service classroom teachers $(n=6)$ are at the intermediate and lower levels while $92.1 \%$ of them $(n=70)$ appear to be at the good level. In Table 4, the descriptive statistics for the digital citizenship levels of the pre-service classroom teachers were displayed. 
Table 4. Mean and Standard Deviation scores for Digital Citizenship Scale and its sub-scales

\begin{tabular}{|c|c|c|c|c|c|c|}
\hline & $\mathrm{N}$ & $\begin{array}{l}\text { Number of } \\
\text { Items }\end{array}$ & Max. & Min. & $\overline{\mathrm{X}}$ & $\mathrm{S}$ \\
\hline $\begin{array}{l}\text { Digital } \\
\text { Citizenship }\end{array}$ & 76 & 63 & 298.00 & 136.00 & 246.96 & 30.57 \\
\hline $\begin{array}{l}\text { Digital } \\
\text { Communication } \\
\text { and Literacy }\end{array}$ & 76 & 24 & 116.00 & 48.00 & 92.21 & 14.35 \\
\hline $\begin{array}{ll}\text { Digital } & \text { Ethics } \\
\text { and Law } & \end{array}$ & 76 & 16 & 80.00 & 38.00 & 66.80 & 9.53 \\
\hline Digital Access & 76 & 7 & 34.00 & 14.00 & 26.84 & 4.35 \\
\hline $\begin{array}{l}\text { Digital Rights } \\
\text { and } \\
\text { Responsibilities }\end{array}$ & 76 & 3 & 15.00 & 5.00 & 10.33 & 2.19 \\
\hline Digital Health & 76 & 5 & 20.00 & 5.00 & 14.16 & 3.11 \\
\hline Digital Safety & 76 & 5 & 25.00 & 10.00 & 20.51 & 3.76 \\
\hline $\begin{array}{l}\text { Digital } \\
\text { Commercing }\end{array}$ & 76 & 3 & 15.00 & 4.00 & 12.06 & 2.77 \\
\hline
\end{tabular}

According to Table 4, the arithmetic mean of digital citizenship levels of pre-service classroom teachers is 246.96 ; the standard deviation is 30.57 . This indicates that the digital citizenship level of pre-service classroom teachers is high.

Regarding the sub-dimensions of the scale, it is observed that the arithmetic mean of Digital Communication and Literacy levels of pre-service classroom teachers is 92.21; the arithmetic mean of Digital Ethics and Law levels of pre-service classroom teachers is 66.80; the arithmetic mean of Digital Access levels of pre-service classroom teachers is 26.84; the arithmetic mean of Digital Rights and Responsibilities is 10.33; the arithmetic mean of Digital Health level is 14.16; the arithmetic mean of Digital Safety level is 20.51; and the arithmetic mean of Digital Commerce level is 12.06 .

\subsection{The Level of Digital Citizenship and Its Sub-Dimensions Among Pre-Service Classroom Teachers by Gender}

The Mann Whitney-U test was conducted to investigate whether there were differences in the levels of the digital citizenship and its sub-dimensions according to gender, and the findings are provided in Table 5.

Table 5. Mann Whitney-U Results for the Digital Citizenship Scale and Its Subscale Scores among Pre-service Classroom Teachers by Gender

\begin{tabular}{|c|c|c|c|c|c|c|}
\hline & Gender & $\mathrm{N}$ & Mean Rank & Total Mean & Mann W.U. & $\mathrm{p}$ \\
\hline \multirow[t]{2}{*}{ Digital Citizenship } & Female & 56 & 41.63 & 2331,00 & \multirow[t]{2}{*}{385.00} & \multirow[t]{2}{*}{$.039 *$} \\
\hline & Male & 20 & 29.75 & 595.00 & & \\
\hline \multirow[t]{2}{*}{ Digital Communication and Literacy } & Female & 56 & 40.54 & 2270.50 & \multirow[t]{2}{*}{445.50} & \multirow[t]{2}{*}{.177} \\
\hline & Male & 20 & 32.78 & 655.50 & & \\
\hline \multirow[t]{2}{*}{ Digital Ethics and Law } & Female & 56 & 42.40 & 2374.50 & \multirow[t]{2}{*}{341.50} & \multirow[t]{2}{*}{$.010^{*}$} \\
\hline & Male & 20 & 27.58 & 551.50 & & \\
\hline \multirow[t]{2}{*}{ Digital Access } & Female & 56 & 40.49 & 2267.50 & \multirow[t]{2}{*}{448.50} & \multirow[t]{2}{*}{.187} \\
\hline & Male & 20 & 32.93 & 658.50 & & \\
\hline \multirow[t]{2}{*}{ Digital Rights and Responsibilities } & Female & 56 & 39.04 & 2186.50 & \multirow[t]{2}{*}{529.50} & \multirow[t]{2}{*}{.717} \\
\hline & Male & 20 & 36.98 & 739.50 & & \\
\hline \multirow[t]{2}{*}{ Digital Health } & Female & 56 & 42.04 & 2354.00 & \multirow[t]{2}{*}{362.00} & \multirow[t]{2}{*}{$.019 *$} \\
\hline & Male & 20 & 28.60 & 572.00 & & \\
\hline \multirow[t]{2}{*}{ Digital Safety } & Female & 56 & 38.82 & 2174.00 & \multirow[t]{2}{*}{542.00} & \multirow[t]{2}{*}{.831} \\
\hline & Male & 20 & 37.60 & 752.00 & & \\
\hline \multirow[t]{2}{*}{ Digital Commercing } & Female & 56 & 39.63 & 2219.50 & \multirow[t]{2}{*}{496.50} & \multirow[t]{2}{*}{.447} \\
\hline & Male & 20 & 35.33 & 706.50 & & \\
\hline
\end{tabular}

$(* \mathrm{p}<.05)$

According to Table 5, conducted to explore whether the scores of the pre-service classroom teachers regarding the level of digital citizenship and its sub-dimensions show a significant variation by gender, the Mann Whitney-U test revealed that; the digital citizenship levels of the pre-service classroom teachers significantly differed by gender $(p<.05)$, while the levels of digital citizenship in sub-dimensions did not significantly deviated by gender in the following dimensions; 
digital communication and literacy, digital access, digital rights and responsibilities, digital security $(p>.05)$. For the other two sub-dimensions, the levels of digital ethics and law, and the levels of digital health, were found to be significantly different $(p<.05)$. As a result, it can be said that the digital citizenship level of women is higher than that of men. This may be due to the fact that women especially, behave more sensitively in recognizing and practicing the rules of digital ethics and law, and pay more attention to the issues of digital health than men.

\subsection{The Perceptions of Pre-service Classroom Teachers Towards Digital Citizenship and Its Sub-dimensions}

The results of the interviews conducted with the pre-service classroom teachers, regarding the concept of digital citizenship, have revealed that the pre-service classroom teachers perceived this concept as the individual who can use the technology effectively (Female=23, Male=8, N=31).

While the majority of the male respondents perceived digital citizenship as e-government applications ( 9 people), most of the female pre-service classroom teachers have noted that they perceived digital citizenship as effective use of technology (Female=23 people). However, the perceptions of pre-service teachers about regarding digital citizenship were identified as rights in the internet environment, virtual environment, gaining knowledge about the use of the internet, and not using technology in an abusive manner.

The sample quotations of the pre-service classroom teachers are as follows;

"Digital citizenship: Knowing and using digital technologies effectively, keeping track of innovations in this area, not using harmful content." (M5, Male, Ali)

"Digital citizenship means a person who uses technology in the right place." (M3, Female, Fatma)

"All kinds of things where people don't interact with each other, are done in virtual environments." (M18, Female, Ceren).

"The digital citizen is a citizen who uses technology accurately and adequately and knows its harms and benefits." (M31, Male, Bayram)

As a result of the analyses obtained from the interviews, conducted with the pre-service classroom teachers, the codes emerged from the explanations of the respondents for the digital citizenship, and are presented in Table 6 to Table 14, respectively. The codes developed are described below, in the headings allocated to each sub-dimension.

Table 6. Views of the Pre-service Classroom Teachers on the Sub-dimension of Digital Literacy

\begin{tabular}{l|l|l}
\hline Digital Citizenship & Female $(f)$ & Male $(f)$ \\
\hline Using technology correctly & 18 & 4 \\
\hline Social Media & 11 & 10 \\
\hline Doing research & 15 & 4 \\
\hline Reading and writing in digital environment & 9 & 2 \\
\hline Shopping & 2 & - \\
\hline Other & 1 & - \\
\hline
\end{tabular}

Sample quotations of the pre-service classroom teachers for digital literacy are as follows:

"The person who has any information and can use it in digital media." (M60, Female, Ayca)

"Continuously reading all kinds of information and articles in digital media." (M56, Female, Gizem)

"Following and reading books, magazines, writers, poets, etc. from the internet." (M25, Male, Ahmet)

"Reading and sharing something on the internet..." (M16, Male, Umut)

Table 7. Views of the Pre-service Classroom Teachers on the Sub-dimension of Digital Commercing

\begin{tabular}{l|l|l}
\hline Digital Commercing & Female $(f)$ & Male $(f)$ \\
\hline Shopping on the internet & 40 & 16 \\
\hline E-commerce & 10 & 3 \\
\hline Being knowledgeable on shopping & 1 & 1 \\
\hline Gaining income & 5 & - \\
\hline
\end{tabular}

Sample quotations of the pre-service classroom teachers for digital commercing are as follows:

"Doing everything about shopping from digital media." (M5, Male, Ali) 
"Making commercial transactions electronically." (M18, Female, Ceren)

"Creating a commercial environment in digital environments." (M41, Female, Dila)

"Earnings gained through Internet and technology." (M21, Male, Ata)

Table 8. Views of the Pre-service Classroom Teachers on the Sub-dimension of Digital Ethics

\begin{tabular}{l|l|l}
\hline Digital Ethics & Female $(\boldsymbol{f})$ & Male $(\boldsymbol{f})$ \\
\hline Obeying the rules of ethics & 28 & 10 \\
\hline Behaving in accordance with ethical rules & 14 & 7 \\
\hline Interpersonal respect & 5 & 2 \\
\hline Accessibility limit & 5 & 1 \\
\hline
\end{tabular}

Sample quotations of the pre-service classroom teachers for digital ethics are as follows:

"To do things that are right in terms of morality in digital environments, or not to do things that are false." (M3, Female, Fatma)

"There are rules to be followed in the virtual environment, respect is important." (M74, Female, Seda)

"Just as there are rules of morality in our normal daily lives, there should be maintenance of respect for each other on the internet." (M76, Male, Emre)

"Internet and virtual environments should be used in accordance with certain etiquette." (M22, Male, Utku)

Table 9. Views of the Pre-service Classroom Teachers on the Sub-dimension of Digital Access

\begin{tabular}{l|l|l}
\hline Digital Access & Female $(f)$ & Male $(f)$ \\
\hline Convenient access to sites & 19 & 7 \\
\hline Access to the Internet & 18 & 6 \\
\hline Getting necessary information & 9 & 7 \\
\hline Easy access to technology & 10 & 5 \\
\hline
\end{tabular}

Sample quotations of the pre-service classroom teachers for digital access are as follows:

"Things like searching over the internet, getting information..." (M9, Female, Ezgi)

"Access to what we want to reach with digital facilities." (M5, Male, Ali)

"Easy to access all kinds of data in digital environment." (M56, Female, Gizem)

"Accessing all kinds of resources, we want to access in the internet environment." (M17, Male, Kemal)

Table 10. Views of the Pre-service Classroom Teachers on the Sub-dimension of Digital Communication

\begin{tabular}{l|l|l}
\hline Digital Communication & Female $(\boldsymbol{f})$ & Male $(f)$ \\
\hline Digital Conversation & 28 & 8 \\
\hline Social Media & 17 & 6 \\
\hline Using communication resources & 6 & 4 \\
\hline Easy communication & 5 & 2 \\
\hline
\end{tabular}

Sample quotations of the pre-service classroom teachers for digital communication are as follows:

"Communicating through video calling, messaging, etc.” (M55, Female, Ece)

"Communicating simply and easily." (M75, Female, İlayda)

"Social media, chatting with people in a virtual environment, creating a social environment." (M23, Male, Akın)

"Shorten communication time using technology, makes it easier." (M71, Male, Ada) 
Table 11. Views of the Pre-service Classroom Teachers on the Sub-dimension of Digital Health

\begin{tabular}{l|l|l}
\hline Digital Health & Female $(\boldsymbol{f})$ & Male $(\boldsymbol{f})$ \\
\hline The effects of technology on our health (eyes, neck...) & 28 & 6 \\
\hline Healthy use & 18 & 6 \\
\hline Health in the technological products (pedometer...) & 6 & 3 \\
\hline Brand Control & 1 & 5 \\
\hline E-Health & 3 & - \\
\hline
\end{tabular}

Sample quotations of the pre-service classroom teachers for digital health are as follows:

"You need to take the right seating position (ergonomics for waist, shoulder, back pain)." (M79, Male, Arda)

"The new pulse measurement on the phone, counting the number of steps, etc.; health issues." (M3, Female, Fatma)

"While using technology, watch out for eye, shoulder health.... and radiation." (M2, Female, Melis)

"Protection from harmful rays emitted by technological devices." (M5, Male, Ali)

Table 12. Views of the Pre-service Classroom Teachers on the Sub-dimension of Digital Security

\begin{tabular}{l|l|l}
\hline Digital Security & Female $(\boldsymbol{f})$ & Male $(\boldsymbol{f})$ \\
\hline Reliable Websites & 24 & 10 \\
\hline Protection of private information & 21 & 8 \\
\hline Encryption & 6 & 2 \\
\hline Fraud & 5 & - \\
\hline
\end{tabular}

Sample quotations of the pre-service classroom teachers for digital security are as follows:

"I think it's necessary to surf the internet more securely. I use reliable sites." (M76, Male, Emre)

"Not sharing private information and secret stuff like passwords used in digital media." (M72, Female, Semra)

"There are pages that will threaten security, you must avoid them." (M71, Male, Ada)

"Not sharing information that could endanger us in digital media." (M3, Female, Fatma)

Table 13. Views of the Pre-service Classroom Teachers on the Sub-dimension of Digital Rights and Responsibilities

\begin{tabular}{l|l|l}
\hline Digital Rights and Responsibilities & Female $(f)$ & Male $(f)$ \\
\hline User privacy/rights & 28 & 10 \\
\hline Rights in digital media & 17 & 8 \\
\hline Freedom & 5 & 2 \\
\hline Access prevention & 6 & - \\
\hline
\end{tabular}

Sample quotations of the pre-service classroom teachers for digital rights and responsibilities are as follows:

"Digital rights and responsibilities are the search and access of individuals without harming another individual within the limits of ethical rules." (M70, Male, Onur)

"Our rights and responsibilities are also in the virtual environment, for example, we should know our rights when shopping, otherwise we should object." (M74, Female, Seda)

"In the digital environment, where someone else's freedom begins, ours ends." (M75, Female, İlayda)

"We also have the right to use technology. For example, we can complain to the one who disturbs us. Nonetheless, we must know our responsibility and not disturb anyone." (M27, Male, İlker)

Table 14. Views of the Pre-service Classroom Teachers on the Sub-dimension of Digital Law

\begin{tabular}{l|l|l}
\hline Digital Law & Female $(f)$ & Male $(f)$ \\
\hline Internet laws & 36 & 14 \\
\hline Digital crime and penalties & 11 & 4 \\
\hline Measures taken by the government & 9 & 2 \\
\hline
\end{tabular}


Sample quotations of the pre-service classroom teachers for digital law are as follows:

"In a bad situation in a digital environment, we can apply for laws and initiate transactions in case of any security threat." (M3, Female, Fatma)

"The actions done in the virtual environment are subject to responsibility and under supervision." (M1, Female, İrem)

"Sites permitted by the state can be accessed." (M10, Male, Alim)

"Rules and penalties for crimes committed in digital media." (M43, Male, Sedat)

5.4 The Perceptions and Recommendations of Pre-service Classroom Teachers Regarding the Applications of Digital Citizenship at the Undergraduate Education

As a result of the analyses, the opinions of the pre-service classroom teachers, regarding the practices in undergraduate education, are presented in Table 15.

Table 15. Views of the Pre-service Classroom Teachers on the Practices Done in Undergraduate Education

\begin{tabular}{l|l|l}
\hline $\begin{array}{l}\text { Perceptions about the practices done in } \\
\text { undergraduate education }\end{array}$ & Female $(\boldsymbol{f})$ & Male $(\boldsymbol{f})$ \\
\hline Lecture presentations & 23 & 10 \\
\hline Using as a technological tool & 20 & 4 \\
\hline Research & 13 & 6 \\
\hline
\end{tabular}

In examining Table 15, it appears that pre-service teachers utilize the technology while preparing for course presentations, doing research for assignments, and using the technology only as a tool in their lessons.

Direct quotations of the pre-service classroom teachers for the respective issues are as follows:

"I have benefited from digital technology in all kinds of research or correspondence." (M3, Female, Fatma)

"We used it in our presentations, usually in teaching classes." (M11, Female, Suna)

"In general, the presentation was used as a tool in slide transfer. Sometimes we used as a sample material for some gains." (M27, Male, İlker)

"We used it as a tool for lesson-related topics, such as Word presentation, slide, movie viewing, and video viewing." (M53, Male, Cem)

Almost all of the pre-service classroom teachers indicated that they did not take a course on digital citizenship.

\section{Discussion}

The result of the study revealed that the pre-service classroom teachers presented primarily high digital citizenship scores. In addition, the findings obtained from interviews and observations, made with the pre-service classroom teachers, are consistent with the responses given by the pre-service classroom teachers in the scale. This may be due to the fact that the pre-service classroom teachers are able to integrate digital citizenship and its sub-dimensions, which are commerce, ethics, literacy, rights and responsibility, law, health, access, communication, and security, into technology; they are aware of technological developments in these sub-dimensions. Indeed, in their study, Kaya and Kaya (2014) identified that the pre-service teachers tried to establish a separate relationship between the concepts, by defining the concepts of digital and citizenship while defining the concept of digital citizenship. Furthermore, it has been observed that pre-service teachers fully associate the items related to digital citizenship and its sub-dimensions to these sub-dimensions during the interview. This can be considered to be that the pre-service teachers have sufficient knowledge about the digital citizenship, and its sub-dimensions.

In terms of gender, there is a significant difference in the digital citizenship levels of the pre-service classroom teachers regarding "digital ethics and law" and "digital health" factors; however, there is no significant difference in "digital communication and literacy", "digital access", "digital rights and responsibilities", "digital security" and "digital commence" factors. In all sub-dimensions of digital citizenship and the total digital citizenship, female pre-service teachers were found to be higher than male pre-service teachers.

There were no gender differences in the studies of İşman and Güngören (2013), Sakallı and Çiftçi (2016), and Bardakc1, Akyüz, Samsa-Yetik and Keser (2014). Aşııı Bilgel ve Usluel Koçak (2013) ve Ono ve Zavodny (2007) indicated that gender did not affect access to ICT (information and communication technologies). Depending on the quantitative studies about digital citizenship, Kaya and Kaya (2014) stated that the digital citizenship level of pre-service teachers does not change by gender. This can also be attributed to the different branches of pre-service teachers participating in the studies. 
Ultimately, Kocadağ (2012) concluded that pre-service teachers have a significant difference in their level of digital citizenship, and that this difference is in favor of male pre-service teachers. In the same way, Çepni, Oğuz and Kılcan (2014) concluded that male students have higher attitude scores towards digital citizenship than female students. In their research, Çukurbaşı and İşman (2014) stated that the digital characteristics of pre-service teachers differ significantly by gender, and that this difference was in favor of male participants. In his study, Bakır (2016) reported that male pre-service teachers had higher mean scores than female pre-service teachers in all dimensions of digital citizenship except for digital ethics and digital law. This result is consistent with the study of Çetin (2015) in which male pre-service teachers have higher mean scores than female ones in literacy.

Erdem (2008) noted that the use of information technology of female pre-service teachers was more ethical than that of males. Genç, Kazez and Fidan (2013) also stated that females are more sensitive to ethical behavior than males. In the study of Uysal (2006), female pre-service teachers are reported to use computers more ethically than males. These results are similar to the "digital ethics" result.

Çoklar (2008) noted that males see themselves competent in the sub-dimensions (social, ethical, legal and humanitarian issues) of the educational technology standards scale. Y1lmaz and Ersoy (2012) expressed that the use of ICT for communication, entertainment and daily purposes significantly differs in favor of male students. The use of ICT for educational purposes was reported not to differ by gender.

Aşıcı Bilgel and Usluel Koçak (2013) found that male students had higher ICT literacy scores than female students; and while female students used ICT for academic purposes more than male students, male students used ICT for entertainment purposes more than female students.

\section{Recommendations}

The level of digital citizenship was examined by using gender variable. In further studies, some of the other variables, which were thought to have an effect on gender, may be studied with larger samples.

The levels of digital citizenship can be compared with the educational internet usage of pre-service teachers in different branches. The relationship between effective citizenship levels and digital citizenship levels of pre-service teachers can be scrutinized.

\section{References}

Aşıc1, B. T., \& Usluel, K. Y. (2013). Investigation of digital divide according related to university students' demographic characteristics. Hacettepe University Journal of Education, 44(44), 73-84.

Aydın, A. (2015). Dijital vatandaşlık. Türk Kütüphaneciliği, 29(1), 142-146.

Bakır, E. (2016). Examining perceptions of preservice classroom teachers in terms of dimensions/elements of digital citizenship. (Unpublished master thesis, Karadeniz Technical University Institute of Educational Sciences, Trabzon, Turkey). Retrieved from: https://tez.yok.gov.tr/UlusalTezMerkezi/

Bardakcı, S., Akyüz, H. İ., Samsa-Yetik, S., \& Keser, H. (2014). Öğretmen Adaylarının Dijital Vatandaşlık Eğilimleri Üzerine Sosyokültürel Bir İnceleme. 8th International Computer \& Instructional Technologies Symposium (ICITS). Trakya University: Edirne.

Bennett, W. L., Wells, C., \& Rank, A. (2009). Young citizens and civic learning: Two paradigms of citizenship in the digital age. Citizenship Studies, 13(2), 105-120. https://doi.org/10.1080/13621020902731116

Burnett, C. (2009). Research into literacy and technology in primary classrooms: an exploration of understandings generated by recent studies. Journal of Research in Reading, 32(1), 22-37. https://doi.org/10.1111/j.1467-9817.2008.01379.x

Büyüköztürk, Ş. (2009). Sosyal bilimler için veri analizi el kitabı. İstatistik, araştırma deseni SPSS uygulamaları ve yorum [Data analysis manual]. Ankara: Pegem Akademi Publishing.

Çepni, O., Oğuz, S., \& Kılcan, B. (2014). İlköğretim Öğrencilerinin Dijital Vatandaşlığa Yönelik Görüşleri. Türkiye Sosyal Araştırmalar Dergisi, 18(3), 251-266.

Çetin, B. (2015). Determination of media and television literacy levels of classroom teacher candidates. Journal of Theory and Practice in Education, 11(1), 171-190.

Çoklar, A. N. (2008). Assessing the self-efficacy of teacher candidates concerning the educational technology standards. (Unpublished doctoral dissertation, Anadolu University Institute of Educational Sciences, Eskişehir, Turkey). Retrieved from: https://tez.yok.gov.tr/UlusalTezMerkezi/

Çukurbaşı, B., \& İşman, A. (2014). Examination of Teacher Candidates' Digital Natives Features (Example of Bartın University). Bartın University Journal of Faculty of Education, 3(1), 28-54. 
https://doi.org/10.14686/BUEFAD.201416206

Engin, G., \& Sarsar, F. (2015). Investigation of primary school teacher candidates' global citizenship levels. International Journal of Human Sciences, 12(1), 150-161. https://doi.org/10.14687/ijhs.v12i1.3159

Erdem, Z. (2008). An evaluation of preservice teachers? ethical usage of information technologies. (Unpublished master thesis, Dokuz Eylül University Institute of Educational Sciences, İzmir, Turkey). Retrieved from: https://tez.yok.gov.tr/UlusalTezMerkezi/

Fraenkel, J. R., \& Wallen, N. E. (2006). How to design and evaluate research in education (6. Edition). New York: McGraw-Hill Book Company.

Genç, Z., Kazez, H., \& Fidan, A. (2013). Çevrimiçi Etik Dışı Davranışlarının Belirlenmesi İçin Bir Ölçek Uyarlama Çalışması/ A Study of University Students' Online Unethical Behaviors. Akademik Bilişim 2013 - Akademik Bilişim Konferansı Bildirileri, 23-25 Ocak 2013. Akdeniz Üniversitesi: Antalya.

Greenhow, C. (2010). Research windows - a new concept of citizenship for the digital age. Learning and Leading with Technology, 37(6), 24.

Gündüz, Ş., \& Odabaşı, F. (2004). The importance of instructional technologies and material development course at pre-service teacher education in information age. The Turkish Online Journal of Educational Technology, 3(1), 43-48.

İşman, A., \& Güngören, Ö. C. (2013). Being Digital Citizen. Procedia - Social and Behavioral Sciences, 106, 551-556. https://doi.org/10.1016/j.sbspro.2013.12.063

Karasar, N. (2005). Bilimsel araştırma yöntemi. (15. Baskı). Ankara: Nobel Yayın Dağıtım.

Kaya, A., \& Kaya, B. (2014). Teacher candidates' perceptions of digital citizenship. International Journal of Human Sciences, 11(2), 346-361. https://doi.org/10.14687/ijhs.v11i2.2917

Kocadağ, T. (2012). Determining the digital citizenship levels of prospective teachers.(Unpublished master thesis, Karadeniz Technical University Institute of Educational Sciences, Trabzon, Turkey). Retrieved from: https://tez.yok.gov.tr/UlusalTezMerkezi/

Kumar, S., \& Vigil, K. (2011). The net generation as preservice teachers: Transferring familiarity with new technologies to educational environment. Journal of Digital Learning in Teacher Education, 27(4), 144-153. https://doi.org/10.1080/21532974.2011.10784671

Lindsey, L. (2015). Preparing teacher candidates for 21st century classrooms: A Study of digital citizenship. (Doctoral dissertation, Arizona State University, Arizona).

Missingham, R. (2009). Encouraging the digital economy and digital citizenship. The Australian Library Journal, 58(4), 386-399. https://doi.org/10.1080/00049670.2009.10735927

O’Brien, T., \& Stavert, B. (2011). Creating good digital citizens. In A. Mendez-Vilas (Ed.), Education in a technological world: Communicating current and emerging research and technological efforts. Badajoz, Spain: Formatex Research, 115-119.

Ono, H., \& Zavodny, M. (2007). Digital inequality: A Five Country Comparison Using Microdata. Social Science Research, 36, 1135-1155. https://doi.org/10.1016/j.ssresearch.2006.09.001

Sakall, H., and \& Çiftçi, S. (2016). The investigation of the relationship between digital citizenship levels and cyber bullying tendencies of prospective primary school teachers. Educational Technology Theory and Practice, 6(2). 100-119.

Uysal, Ö. (2006). Views of teacher trainees on computer ethics. (Unpublished master thesis, Anadolu University Institute of Educational Sciences, Eskişehir, Turkey). Retrieved from: https://tez.yok.gov.tr/UlusalTezMerkezi/

Yıldırım, A., \& Şimşek, H. (2006). Sosyal bilimlerde nitel araştırma yöntemleri. Ankara: Seçkin Publishing.

Yllmaz, F., \& Ersoy, A. (2012). An Investigation of Digital Divide among Fifth Grade Students in Terms of Various Variables: Diyarbakır Case. Mersin University Journal of the Faculty of Education, 8(1), 29-42.

\section{Copyrights}

Copyright for this article is retained by the author(s), with first publication rights granted to the journal.

This is an open-access article distributed under the terms and conditions of the Creative Commons Attribution license which permits unrestricted use, distribution, and reproduction in any medium, provided the original work is properly cited. 